BIOMEDICAL AND BIOSOCIAL ANTHROPOLOGY
$\begin{gathered}\text { Official Journal of the International Academy } \\ \text { of Integrative Anthropology } \\ \text { journal homepage: http://bba-journal.com }\end{gathered}$

\title{
Forms of infectious complications after use of metal foreign bodies of the auricle and determination of the ability of detected microorganisms to biofilm formation
}

Mishina M. M., Bondarenko O. V.

Kharkiv National Medical University, Kharkiv, Ukraine

\section{ARTICLE INFO}

Received: 23 September 2020

Accepted: 19 October 2020

UDC: $579.262: 616.288 .71-089.85-06-$

002.3-022.7

\section{CORRESPONDING AUTHOR}

e-mail: mishina1969mmm@gmail.com Mishina M. M.
Ear or nose are quite vulnerable to foreign bodies. Foreign bodies cause various side effects in the body. A special ategory consists of foreign bodies that are introduced for aesthetic purposes, in particular piercing products. Decoration implanted in the tissues of the ear or nose is a foreign body and is a field of increased contamination and reproduction of pathogenic and opportunistic microorganisms. The aim of the study was to determine the infectious forms of complications that occurred after prolonged use of metal foreign bodies and to study the ability of biofilms by microorganisms isolated from the pathological contents of the foreign body of the auricle. 93 patients who applied to the ENT department of Kharkiv Regional Hospital for complications after implantation of metal foreign bodies and 10 people, control group, which had no foreign bodies, and were randomly selected from healthy individuals, were examined, to determine the qualitative composition of the microbiocenosis of the auricle skin. The material for the study was pathological discharge from a foreign body of the auricle. The microbiological study was performed using MICRO-LA-TEST identification kits. Studies of the formation of biofilms were studied by determining the ability of bacterial strains to adhere to the surface of polystyrene. The obtained cultures were washed with suspension media individual for each family of bacteria. The optical density of bacterial suspensions was measured using a microplate reader "MultiskanEX" (type 355). Statistical analysis of the obtained data was performed using MSExcel, Statisica 10 software. As a result of the conducted researches the dependence between the development of infectious complications of the auricle in the presence of metal foreign bodies and the microbiocenosis of the pathological focus was revealed. The study allowed to establish the structure of the microbial landscape of the skin of the auricle in the area of the metal foreign body, to determine the dominant forms of complications of infectious origin, after prolonged use of metal foreign bodies and to study the ability to form biofilms by microorganisms from different metals. The ability of various types of microorganisms to form biofilms when using products from different types of metals has been studied. It is established that the use of metal foreign bodies made of silver and gold reduces the risk of purulent-inflammatory process. It is proved that the optical density of biofilms of most microorganisms isolated from the pathological contents of the area of foreign bodies made of silver and gold is significantly lower than when using steel and titanium products.

Keywords: microbiocenosis, microorganisms, purulent-inflammatory process, auricle, complications, foreign bodies, biofilms.

\section{Introduction}

The microbial landscape of the skin of the auricle under the influence of external factors has changed over time. If previously the leading causative agent of purulentinflammatory complications of implantation of metal foreign bodies was considered Staphylococcus aureus, recently the role of Pseudomonas aeruginosa has increased to an average of $78 \%$ of cases [29]. In some cases, bacterial or bacterial-fungal associations act as an etiotropic factor. The ratio of different types of microorganisms that are part of the microflora of the skin of the auricle can serve as an 
indicator of the functional value of the mechanisms of protection of the microorganism. The microflora of the skin is the result of a set of complex relationships of micro- and macroorganisms, taking into account the influence of many aggressive environmental factors, including the puncture of the auricle [14]. It is known that most bacteria in the environment exist in the form of biofilms attached to substrates, the formation of which is a complex and regulated biological process [1, 27]. The formation of biofilms by microorganisms is one of the mechanisms of bacterial survival in the environment $[5,17]$.

From the studied features of skin microbiocenosis in pathological conditions, namely in the occurrence of purulent-inflammatory process, the existence of the phenomenon of mutual enhancement of pathogenicity in associations of fungi of the genus Candida and bacteria has been proved [23]. In this case, fungi cause sensitization of the body, suppress the functional activity of cellular immunity and neutrophil phagocytosis, contribute to the development of allergodermatoses and the spread of microbial infection [2].

Under stressful conditions for the body, which includes the implantation of metal foreign bodies, there is a selection of opportunistic pathogens that acquire the properties of pathogenicity and persistence $[4,8]$. As a result, the translocation of microbes and toxins into the bloodstream and infection of lymphoid tissue occurs and is maintained, so opportunistic pathogens can become etiological agents of infectious diseases of the skin. Today, most microbiologists recognize that a significant number of microorganisms in natural and artificial environments exist in the form of structured, attached to the surface of groups biofilms, which show a change in phenotype, expressed by changes in growth parameters and expression of specific genes $[9,15,19]$. The film usually includes $15-20 \%$ of the bacterial mass, which is firmly attached to a surface, and $80-85 \%$ of the protective matrix, which reduces the effect of antibiotics and antiseptics on target microcultures by tens, hundreds and even thousands of times [20, 28]. Biofilms are continuously changing heterogeneous groups that may consist of a single species of bacteria or fungi or, more often, may be polymicrobial. It is known that the formation and development of microbial communities is coordinated by the system "quorum sensing" (QS), the main function of which is the production of signaling molecules and the ability of bacteria to perceive these signals [7]. The QS system controls the cell density of the bacterial population, the production of many extracellular pathogenic factors, which provides bacteria with the opportunity to overcome the protective mechanisms of the macroorganism during infection [21]. In the case of QS inhibition, the production of bacterial virulence factors is reduced and the formation of the biofilm is disrupted $[12,28]$.

The purpose of the study is to determine the infectious forms of complications that occurred after prolonged use of metal foreign bodies and to study the ability to form biofilms by microorganisms isolated from the pathological contents of the foreign body of the auricle.

\section{Materials and methods}

The work was performed on the basis of the ENT clinic of Kharkiv National Medical University. We examined 93 patients who applied to the ENT department of the Kharkiv Regional Hospital for complications after implantation of metal foreign bodies and 10 people, control group, to determine the quality of the microbiocenosis of the skin of the auricle, who had no foreign bodies, and were randomly selected from healthy persons.

The obtained material from the area of the foreign body of the auricle was taken and delivered to the laboratory in accordance with the requirements of collection and delivery of material for microbiological laboratories proposed by the Shupyk National Medical Academy of Postgraduate Education (Kyiv). The material for the study was pathological discharge from a foreign body of the auricle.

The study was conducted in compliance with the basic bioethical provisions of the Council of Europe Convention on Human Rights and Biomedicine (04.04.1997), the Helsinki Declaration of the World Medical Association on the ethical principles of scientific medical research with human participation (1964-2008), and the order of Ministry of Health of Ukraine № 690 dated 23.09.2009. The conclusion of the Commission on Ethics and Bioethics of Kharkiv National Medical University confirms that the study was conducted in compliance with human rights, in accordance with current legislation in Ukraine, meets international ethical requirements and does not violate ethical standards in science and standards of biomedical research.

The microbiological study was performed using MICROLA-TEST identification kits, which are designed for standard identification using micromethods and allow the identification of most clinically important microorganisms in a short time. The following nutrient media were used for primary seeding: $5 \%$ blood agar, Chistovich's yellow-salt agar, Endo medium, Hottinger's medium, Tarozzi's semiliquid medium, Saburo's medium.

When determining the concentration of microbial cells, the percentage of viable cells is determined, which is determined by the number of living cells per unit volume of suspension (number of colony-forming units in $\mathrm{ml}$ - CFU/ $\mathrm{ml}$ ). Standardization of the microbial suspension was performed using the McFarland turbidity standard (McF McFarland) using a device "Densi-La-Meter". Studies of the formation of biofilms were studied by determining the ability of bacterial strains to adhere to the surface of polystyrene in 96-well plates for enzyme-linked immunosorbent assay [17, $20,26]$. Cultures were grown according to generally accepted methods in microbiology on the suspension media recommended for each family of bacteria. The obtained cultures were washed with suspension media individual for each family of bacteria. The optical density of the initial 
bacterial suspension was measured on a "Densi-La-Meter" and adjusted to the appropriate McFarland concentration using a suspension medium. The optical density was measured using a microplate reader "MultiskanEX" (type 355), which is a photometer with replaceable filters and is able to perform standard photometric measurements.

Statistical analysis of the obtained data was performed using MSExcel software, Statisica 10 [3, 30]. These programs have a complete set of proven statistical procedures, with an in-depth understanding of the relationships between data and the structure of forecasts [30]. The results of the mean values of the indicators between the groups were compared using parametric (Student's test) and non-parametric criteria ( $U$ Mann-Whitney, $X^{2}$ Pearson) $[13,22]$.

The probability of intergroup differences of particles is calculated using Fisher's exact criterion $\varphi$. We used the method of correlation analysis as well as methods of descriptive statistics. The difference between the indicators was considered probable at $p<0.05$.

\section{Results}

The total number of the group was 93 people, with an absolute predominance of women (94.6\%), which corresponds to a gender ratio of $1: 18$. The structure of complications found in patients of the clinical group was dominated by perichondritis of the auricle and secondary infection; the category of "other" complications included atheroma formation, rupture and defects of the earlobe, etc.

In total, 26 cases of secondary soft tissue infection, 18 cases of auricle defects, 15 cases of perichondritis, 7 cases of contact dermatitis, 7 cases of keloid scars, and 20 other complications were registered in the structure of complications, incl. atheroma and ruptures of the earlobe.

When comparing the frequency of complications, it was found that people who use silver, gold or composite jewelry, the chances of developing different types of pathology are almost the same (Table 1).

Exclusion criteria were the presence of traumatic brain injury, generalized infectious, somatic and genetic diseases.

Table 2 shows the results of comparing the frequency of complications in patients with metal foreign bodies of the clinical group.

The structure of the microbiocenosis of the skin of the auricle of the control group was represented by the following microorganisms: Peptostreptococcus spp. - $(2.2 \pm 0.2) \times 10^{2}$

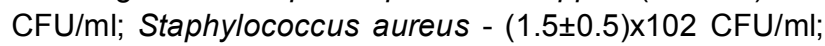
Micrococcus spp. - $(1.4 \pm 0.3) \times 10^{1} \mathrm{CFU} / \mathrm{ml}$; Enterococcus spp. - $(2.1 \pm 0.2) \times 10^{1} \mathrm{CFU} / \mathrm{ml}$; Candida spp. - $(2.4 \pm 0.3) \mathrm{x}$ $10^{2} \mathrm{CFU} / \mathrm{ml}$; Actinomyces spp. - $(1.6 \pm 0.2) \times 10^{1} \mathrm{CFU} / \mathrm{ml}$; Staphylococcus epidermidis - $(1.4 \pm 0.2) \times 10^{2} \mathrm{CFU} / \mathrm{ml}$; Enterobacter spp. - $(2.2 \pm 0.4) \times 10^{1} \mathrm{CFU} / \mathrm{ml}$; E. coli $(1.4 \pm 0.1) \times 10^{1} \mathrm{CFU} / \mathrm{ml}$; Staphylococcus pyogenes $(1.1 \pm 0.1) \times 10^{1} \mathrm{CFU} / \mathrm{ml}$.

As a result of the study, it was found that out of 93 people, complications occurred in 21 people $(22.6 \%)$ who used
Table 1. Comparison of the frequency of complications of metal foreign bodies depending on the chemical composition of jewelry.

\begin{tabular}{|c|c|c|c|c|}
\hline & Silver & Gold & Alloy & Titanium \\
\hline Silver & & $\begin{array}{l}2=0.950 \\
p=0.333\end{array}$ & $\begin{array}{l}2=0.522 \\
p=0.471\end{array}$ & $\begin{array}{c}X 2=7.547 \\
p=0.011 \\
\varphi 2=0.041\end{array}$ \\
\hline Gold & & & $\begin{array}{l}2=3.563 \\
p=0.058\end{array}$ & $\begin{aligned} X 2 & =13.424 \\
p & =0.000 \\
\varphi 2 & =0.041\end{aligned}$ \\
\hline Alloy & & & & $\begin{array}{c}X 2=7,042 \\
p=0.012 \\
\varphi 2=0.041\end{array}$ \\
\hline
\end{tabular}

Table 2. Stratification characteristics of complications in individuals of clinical groups of the contingent of the prospective stage of the study.

\begin{tabular}{|c|c|c|c|c|}
\hline \multirow{2}{*}{$\begin{array}{l}\text { Number of } \\
\text { examined }\end{array}$} & \multirow{2}{*}{$\begin{array}{c}\text { Material of } \\
\text { products }\end{array}$} & \multirow[t]{2}{*}{ Complications } & \multicolumn{2}{|c|}{$\begin{array}{c}\text { Number of } \\
\text { complications }\end{array}$} \\
\hline & & & absolute & $\%$ \\
\hline \multicolumn{5}{|c|}{ Clinical group (persons with implants in the auricles), $n=93$} \\
\hline \multirow{3}{*}{$\begin{array}{l}\text { I group } \\
(n=21)\end{array}$} & \multirow{3}{*}{ silver } & atheroma & 12 & 12.9 \\
\hline & & contact dermatitis & 5 & 5.4 \\
\hline & & secondary infection & 4 & 4.3 \\
\hline \multirow{3}{*}{$\begin{array}{l}\text { II group } \\
(n=25)\end{array}$} & \multirow{3}{*}{ gold } & perichondritis & 7 & 7.5 \\
\hline & & secondary infection & 11 & 11.8 \\
\hline & & keloid scars & 7 & 7.5 \\
\hline \multirow{5}{*}{$\begin{array}{l}\text { III group } \\
(n=37)\end{array}$} & \multirow{5}{*}{ alloy } & rupture of the earlobe & 6 & 6.5 \\
\hline & & auricles defect & 13 & 14.0 \\
\hline & & contact dermatitis & 2 & 2.2 \\
\hline & & perichondritis & 8 & 8.6 \\
\hline & & secondary infection & 8 & 8.6 \\
\hline \multirow{3}{*}{$\begin{array}{l}\text { IV group } \\
(n=10)\end{array}$} & \multirow{3}{*}{ titanium } & rupture of the earlobe & 2 & 2.2 \\
\hline & & auricles defect & 5 & 5.4 \\
\hline & & secondary infection & 3 & 3.2 \\
\hline
\end{tabular}

silver products (group I). In the microbiological analysis of patients in the area of a foreign body in patients with atheroma, the degree of contamination of Staphylococcus aureus $(5.8 \pm 0.4) \times 10^{4}$, S. pyogenes $(7.4 \pm 0.8) \times 10^{3}$, Staphylococcus epidermidis $(5.4 \pm 0.6) \times 10^{3}$, Candida spp. $(4.1 \pm 0.8) \times 10^{2}$ was 2 times higher than in the control group. However, their number is acceptable values for a normal microbial landscape $\left(n=x 10^{1-4}\right)$. The analysis of the condition of the microflora of the skin of the auricle of patients with contact dermatitis showed that the number of opportunistic pathogens did not exceed normal values and corresponded to the control group. Among the complications after prolonged wearing of silverware, was a secondary infection, which is localized in the area of the foreign body. As a result of the study it was found that the degree of contamination of the foreign body area was quite high, in the area of secondary infection were isolated: Staphylococcus aureus $(9.6 \pm 0.8) \times 10^{8}$ $\mathrm{CFU} / \mathrm{ml}$; Staphylococcus epidermidis $(6.3 \pm 0.2) \times 10^{6} \mathrm{CFU} / \mathrm{ml}$; Candida spp. $(3.4 \pm 0.4) \times 10^{6} \mathrm{CFU} / \mathrm{ml}$, which were the 
etiological factors of secondary infection in the area of the metal foreign body. Pathogenic properties of microbial contamination were manifested due to the reproduction of microorganisms and their penetration from the surface into the wound tissue.

Further studies were performed to determine the ability of microorganisms sown from the pathological contents of a foreign body to form biofilms. According to the results of the study, it was found that all isolates formed dense diurnal

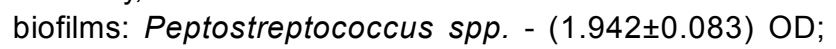
Staphylococcus aureus - (2.959 \pm 0.091$)$ OD; Micrococcus spp. - (1.683 \pm 0.042$)$ OD; Enterococcus spp. - (2.214 \pm 0.071$)$ OD; Candida spp. - (3.622 \pm 0.091$)$ OD.; Actinomyces spp. $(3.462 \pm 0.083)$ OD; Staphylococcus epidermidis -

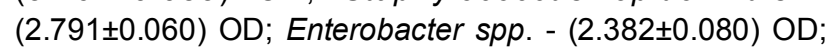

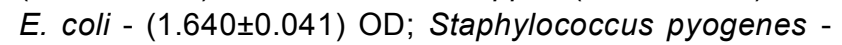
(2.732 \pm 0.091$)$ OD.

Among 93 people, 25 (26.9\%), who wore gold products, had complications in the form of perichondritis and keloid scars by 7 and 11 - secondary infections of the metal foreign body, group II. Microbiological examination of patients with perichondritis revealed that the microbial landscape of the skin of the auricle of the experimental group of patients differed from the control group in content, Staphylococcus aureus $(8.4 \pm 0.9) \times 10^{4}$, Staphylococcus pyogenes $(6.3 \pm 0.5) \times 10^{3}$, Candida spp. $(6.2 \pm 0.6) \times 10^{3}$ Ta $E$. coli $(1.4 \pm 0.2) \times 10^{4}$, which exceeded the contamination of the foreign body area of the control group by 2 - 3 degrees. However, their number corresponded to the values of the normal microflora of the skin of the auricle. Among the complications of wearing gold products is the occurrence of secondary infection. As a result of the study, as in the use of silver products, etiological agents found that the degree of contamination of the foreign body was an order of magnitude higher than in the group of patients who used silver products and $3-7$ orders of magnitude higher than in the control group. From the area of secondary infection were identified: Staphylococcus aureus $(4.6 \pm 0.4) \times 10^{9} \mathrm{CFU} /$ $\mathrm{ml}$; Staphylococcus epidermidis $(3.7 \pm 0.3) \times 10^{7} \mathrm{CFU} / \mathrm{ml} ; E$. coli $(4.8 \pm 0.4) \times 10^{7} \mathrm{CFU} / \mathrm{ml}$; Enterobacter $(8.6 \pm 0.8) \times 10^{7} \mathrm{CFU} /$ $\mathrm{ml}$; Candida spp. (9.8 \pm 0.3$) \times 10^{6} \mathrm{CFU} / \mathrm{ml}$; Actinomyces spp. $(7.8 \pm 0.8) \times 10^{5}$. It was found that the microorganisms isolated from the pathological content formed dense biofilms: Peptostreptococcus spp. - (1.986 \pm 0.082$)$ OD; Staphylococcus aureus - (2.312 \pm 0.093$)$ OD; Micrococcus

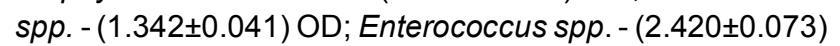

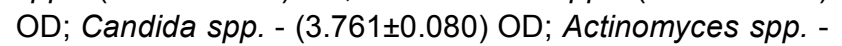
(3.521 \pm 0.062$)$ OD; Staphylococcus epidermidis -

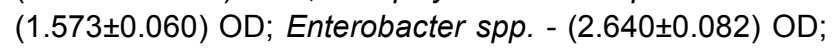
E. coli - (1.462 \pm 0.044$)$ OD; Staphylococcus pyogenes -

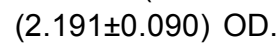

Among the identified complications in patients wearing gold products, keloid scars were observed in $7.0 \%$. When determining the structure of the microbiocenosis of the skin of the auricle of patients with keloid scars, after using gold products, it was found that there was no significant difference between the composition of microorganisms in the normoflora of the control group and the experimental.

It was found that among the persons who sought help $37(11.5 \%)$ used alloy products, group III. Of these, 6 cases of rupture of the earlobe, 13 - ear defects, 8 cases of perichondritis and secondary infection and 2 - contact dermatitis.

Microbiological examination showed that the degree of contamination of the skin of the auricle of patients with rupture of the earlobe when using surgical alloy products was higher by 2 - 3 orders of magnitude than in the control group. The microflora was presented: Staphylococcus aureus $(5.8 \pm 0.4) \times 10^{6} \mathrm{CFU} / \mathrm{ml}$; Peptostreptococcus spp. (8.2 \pm 0.6$) \times 10^{6} \mathrm{CFU} / \mathrm{ml}$; E. coli $(2.9 \pm 0.8) \times 10^{6} \mathrm{CFU} / \mathrm{ml}$; Staphylococcus epidermidis $(5.4 \pm 0.6) \times 10^{6} \mathrm{CFU} / \mathrm{ml}$; Enterobacter spp. (7.2 \pm 0.9$) \times 10^{6} \mathrm{CFU} / \mathrm{ml}$; Candida spp. $(4.1 \pm 0.8) \times 10^{6} \mathrm{CFU} / \mathrm{ml}$. A complication after prolonged wearing of surgical alloy products was the occurrence of contact dermatitis in the area of a foreign body. The analysis of the condition of the microflora of the skin of the auricle showed that the degree of microbial contamination corresponded to the control group. Of all cases of complications after wearing alloy products, perichondritis of the auricle was detected in $21.6 \%$. The structure of the microbiocenosis was presented by: E. coli $(6.8 \pm 0.3) \times 10^{6}$ CFU/ml; Staphylococcus epidermidis $(2.4 \pm 0.7) \times 10^{6} \mathrm{CFU} /$ $\mathrm{ml}$; Enterobacter spp. $(6.7 \pm 0.8) \times 10^{6} \mathrm{CFU} / \mathrm{ml}$ тa Actinomyces spp. $(4.2 \pm 0.3) \times 10^{5} \mathrm{CFU} / \mathrm{ml}$.

After a microbiological study, it was found that the degree of contamination in the area of foreign bodies in secondary infection was quite high, and we identified: Staphylococcus aureus $(6.8 \pm 0.6) \times 10^{9} \mathrm{CFU} / \mathrm{ml}$; Staphylococcus epidermidis (3.8 \pm 0.4$) \times 10^{9} \mathrm{CFU} / \mathrm{ml}$; Candida spp. $(8.4 \pm 0.8) \times 10^{6} \mathrm{CFU} /$ $\mathrm{ml}$; E. coli $(5.4 \pm 0.6) \times 10^{8} \mathrm{CFU} / \mathrm{ml}$; Enterobacter spp. $(4.2 \pm 0.5) \times 10^{8} \mathrm{CFU} / \mathrm{ml}$, which were the etiological factors of secondary infection in the area of foreign bodies. A particularly favorable moment for the development of infection was the presence of damaged tissues and hemorrhages in the wound, which contributed to the development of microorganisms. The main form of bacterial existence is biofilms, not individual planktonic cells. Being in this phenotypic form for a long time, microorganisms produce extracellular polysaccharides and become more tolerant to biocides, namely antibiotics, antiseptics and disinfectants and recover quickly after mechanical destruction, and again form dense biofilms within 24 hours. Therefore, according to the results of the study, it was found that all isolates formed dense daily biofilms:

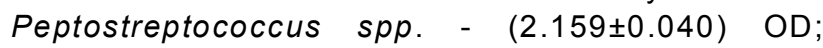
Staphylococcus aureus - (2.942 \pm 0.082$)$ OD; Micrococcus

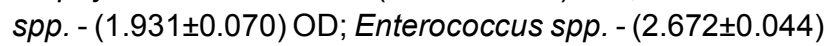

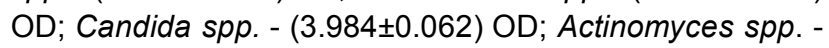
(3.841 \pm 0.083$)$ OD; Staphylococcus epidermidis -

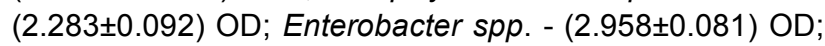
E. coli - (2.194 \pm 0.060$)$ OD; Staphylococcus pyogenes (2.681 \pm 0.044$)$ OD. 


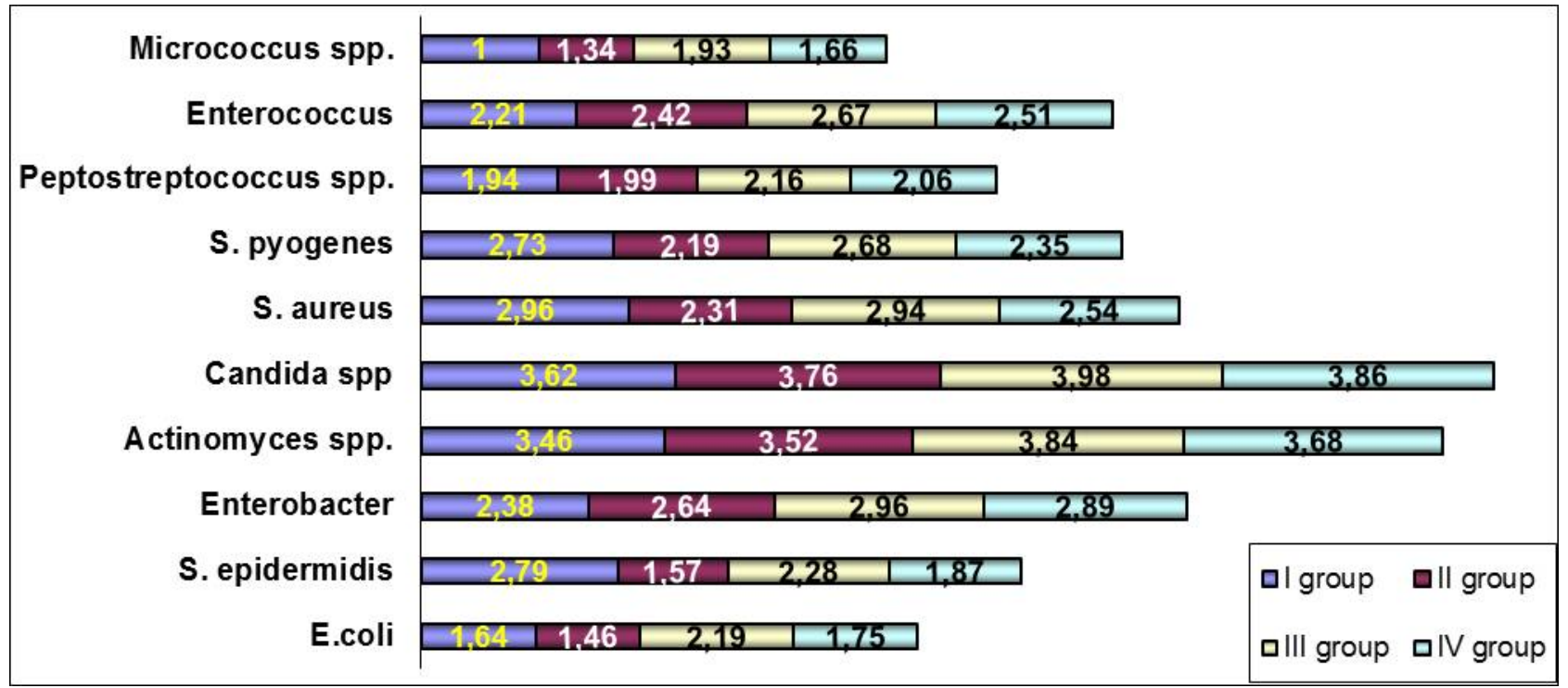

Fig. 1. Optical density of biofilms formed by microorganisms isolated from the zone of metal foreign bodies.

In the study of the group of patients who used titanium products - $10(10.8 \%)$, group IV. The structure of complications was represented by: ruptures of the earlobe when wearing tunnels in 2 patients, in 5 - ear defects and in 3 - secondary infection of metal foreign bodies.

The microbiological study found that the degree of contamination of the skin of the auricle of patients with rupture of the earlobe after using titanium products was higher than in the control group, the microflora was represented by: Staphylococcus aureus $4 \times 10^{7} \mathrm{CFU} / \mathrm{ml}$; Peptostreptococcus spp. $9 \times 10^{5} \mathrm{CFU} / \mathrm{ml}$; E. coli $8 \times 10^{6} \mathrm{CFU} /$ $\mathrm{ml}$; Staphylococcus epidermidis $8 \times 10^{7} \mathrm{CFU} / \mathrm{ml}$; Enterobacter spp. $4 \times 10^{6} \mathrm{CFU} / \mathrm{ml}$; Candida spp. $7 \times 10^{4} \mathrm{CFU} /$ $\mathrm{ml}$ мл; Staphylococcus pyogenes $9 \times 10^{5} \mathrm{CFU} / \mathrm{ml}$; Micrococcus spp. $8 \times 10^{5} \mathrm{CFU} / \mathrm{ml}$, the number of which exceeded normal values of skin colonization by these microorganisms.

In the study of the area of secondary infection were identified: $E$. coli $(3.6 \pm 0.3) \times 10^{7} \mathrm{CFU} / \mathrm{ml}$, Staphylococcus aureus $(8.4 \pm 0.8) \times 10^{8} \mathrm{CFU} / \mathrm{ml}$; Staphylococcus epidermidis (6.5 \pm 0.6$) \times 10^{8} \mathrm{CFU} / \mathrm{ml}$; Candida spp. $(4.2 \pm 0.4) \times 10^{5} \mathrm{CFU} /$ $\mathrm{ml}$, Enterobacter $(3.9 \pm 0.4) \times 10^{7} \mathrm{CFU} / \mathrm{ml}$; Enterococcus (4.6 \pm 0.4$) \times 10^{6} \mathrm{CFU} / \mathrm{ml}$, which were the etiological agents of secondary infection. Further research was conducted to determine the ability of microorganisms sown from the pathological contents of the foreign body zone to form biofilms. It is proved that when using titanium products, from pathological secretions microorganisms had the ability to form dense biofilms, forming an association of microbes: Candida albicans, E. coli, Staphylococcus aureus та Staphylococcus epidermidis. The optical density of biofilms of microorganisms isolated from the pathological contents of the area of the foreign bodies of the auricle using titanium products were significantly higher than those used when using silver or gold products:
Peptostreptococcus spp. - $\quad(2.061 \pm 0.042)$ OD; Staphylococcus aureus - (2.540 \pm 0.073$)$ OD; Micrococcus spp. - (1.661 \pm 0.041$)$ OD; Enterococcus spp. - (2.512 \pm 0.032$)$ OD; Candida spp. - (3.864 \pm 0.040$)$ OD; Actinomyces spp. $(3.683 \pm 0.043)$ OD; Staphylococcus epidermidis -

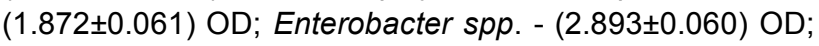
E. coli - (1.753 \pm 0.040$)$ OD; Staphylococcus pyogenes $(2.531 \pm 0.042)$ OD.

\section{Discussion}

Analyzing the data obtained, it can be argued that the number of microorganisms that colonize the skin of the auricles increases in the presence of foreign bodies of alloys and titanium. Prolonged use of metal foreign bodies made of silver and gold reduces the possibility of purulentinflammatory process and prevents the formation of dense biofilms, as one of the main factors of pathogenicity and resistance of microorganisms to antimicrobial drugs.

The formation of biofilms is one of the main strategies that increases the survival of bacteria in the environment, including in the host organism [6]. The ability of microorganisms to exist in biofilms creates great difficulties for medical practice $[10,29]$, as it significantly increases the resistance of bacteria to antibacterial drugs [16, 21], as well as to the effects of disinfectants [18], adverse environmental factors such as low or high $\mathrm{pH}$ levels, high osmotic power and the body's immune defenses [11]. The formation of bacterial biofilms on implants and equipment, catheters, artificial heart valves, lenses, venflons is the cause of a number of purulent-inflammatory processes with severe course [16]. Despite its great popularity and prevalence, the implantation of metal foreign bodies in the auricles has certain problems related to human health. The implantation of metal foreign bodies is associated with perforation of the skin, mucous membranes, muscles, 
cartilage, with the subsequent implantation in them of various products made of surgical steel, titanium, noble and polymeric materials $[3,24]$. Then there may be complications: violation of the microbiocenosis of the skin, purulent-inflammatory processes of the ear or nose, the formation of keloid and hypertrophic scars, bleeding, defects of the auricles, allergic reaction to foreign body material $[9,25]$. In case of insufficient observance of the rules of asepsis, namely: use of non-sterile instruments, insufficient treatment of the implantation site, violation of care techniques after implantation, use of low-quality products, the wound is infected with pathogenic microorganisms [24].

This study showed that the predominant forms of complications of infectious origin, after prolonged use of metal foreign bodies, are perichondritis of the auricle 16.1 $\%$ and secondary infection $27.9 \%$. Since one of the main factors of non-specific protection of the body from environmental microorganisms is the skin, those microorganisms that are opportunistic pathogens and contaminate our skin, when this mechanical barrier is damaged, due to the emergence of a favorable environment (blood, serum in place of damage), begin to show their pathogenic factors. Among them, toxins, pathogenic enzymes and the ability to form biofilms, which cause specific inflammation, which is manifested by infectiousinflammatory processes. It was proved that microorganisms that are isolated from the area of the metal foreign body had the ability to form dense biofilms. The formation of biofilms by isolated microorganisms is one of the mechanisms of the existence of bacteria in the environment [21]. Biofilms are highly organized, mobile, heterogeneous biological systems, which consist of actively

\section{References}

[1] Afinogenova, A. G., \& Darovskaia, E. N. (2011). Микробные биопленки ран: состояние вопроса [Microbial biofilms injuries: state of the question]. Травматология и ортопедия Poccuu - Traumatology and Orthopedics of Russia, 3(61), 119-125.

[2] Alekseeva, N. V., Stepanova, T. V., Tolordava, E. R., \& Romanova, lu. M. (2010). Разработка средств борьбы с биопленками: влияние препарата "Лапрот" (на основе человеческого лактоферрина) и антибиотика ципрофлоксацина на рост и процесс образования биопленок бактериями Pseudomonas aeruginosa in vitro [Development of means of combating biofilms: the effect of the drug "Laprot" (based on human lactoferrin) and the antibiotic ciprofloxacin on the growth and formation of biofilms by the bacteria Pseudomonas aeruginosa in vitro]. Медицинский алфравит - Medical alphabet, 3(15), 6-11.

[3] Bashkatov, B., \& Surinov, А. (2019). Международная статистика. Учебник для бакалавриата и магистратуры [International statistics. Textbook for undergraduate and graduate programs]. М.: Юрайт - М.: Yuright.

[4] Beloborodova, N. V., \& Bairamov, I. T. (2010). Влияние комбинации кларитромицина с имипенемом на формирование микробной биопленки Pseudomonas aeruginosa [Effect of the combination of clarithromycin with imipenem on the functioning cells and cells at rest, enclosed in an exopolymer matrix [6]. They may consist of one or more species of microorganisms [7]. It was previously thought that microorganisms form biofilms on medical devices, such as catheters, endotracheal tubes, IUDs, contact lenses [8]. Currently, it is shown that biofilms of microorganisms are detected in more than $90 \%$ of cases of purulent-inflammatory diseases [9]. Under natural conditions, organisms exist and show their activity, usually in associations, which can change under the influence of new objects introduced into the biosphere, which did not exist before, for example, synthetic polymeric materials and products from them [14].

Studies have shown that the optical density of biofilms of the detected microorganisms was quite different and depended on the type of metal and the type of microorganism (Fig. 1).

Microscopic examination of mixed biofilms revealed that the use of metal foreign bodies made of steel and titanium produces dense biofilms, compared with biofilms formed by microorganisms when using silver and gold products.

\section{Conclusions}

1. The predominant forms of complications of infectious origin, after long-term use of metal foreign bodies, are perichondritis of the auricle $16.1 \%$ and secondary infection $27.9 \%$.

2. Studies have shown that the use of silver and gold products prevents the formation of dense biofilms, as one of the factors of pathogenicity and resistance of microorganisms, as well as reduces the possibility of purulent-inflammatory processes of the auricle.

formation of the microbial biofilm of Pseudomonas aeruginosa]. Инфекции в хирураии - Infections in surgery, 8(2), 71-74.

[5] Fadeev, S. B., Nemtseva, N. V., Perunova, N. B., Tarasenko, V. S., \& Bukharin, O. V. (2010). Формирование биопленок возбудителями раневой инфекции и флегмон мягких тканей [Formation of biofilms by causative agents of wound infections and phlegmons of soft tissues]. Xupypz - Surgeon, (1), 11-18.

[6] Flemming, H. C., \& Wingender, J. (2010). The biofilm matrix. Nature reviews microbiology, 8(9), 623-633. doi: 10.1038/ nrmicro2415

[7] Galimzianov, Kh. M., Bashkina, O. A., Dosmukhanova, E. G. Abdrakhmanova, R. O., Demina, lu. Z., Daudova, A. D., ... \& Rubalskii, E. О. (2018). Клиническое значение биопленкообразования у бактерий [Clinical significance of biofilm formation in bacteria]. Астраханский медицинский журнал - Astrakhan Medical Journal, 13(4), 32-42. doi: 10.17021/ 2018.13.4.32.42

[8] Gefen, O., Chekol, B., Strahilevitz, J., \& Balaban, N. Q. (2017). TDtest: easy detection of bacterial tolerance and persistence in clinical isolates by a modified disk-diffusion assay. Scientific reports, 7(1), 1-9. doi: 10.1038/srep41284

[9] James, G. A., Swogger, E., Wolcott, R., Pulcini, E. D., Secor, P., Sestrich, J., ... \& Stewart, P. S. (2008). Biofilms in chronic wounds. Wound Repair and regeneration, 16(1), 37-44. doi: 
10.1111/j.1524-475X.2007.00321.x

[10] Khmel, I. A. (2018). Биопленки бактерий и связанные с ними трудности медицинской практики [Bacterial biofilms and associated medical practice difficulties]. Access mode: https://img.ras.ru/files/center/biofilms.doc

[11] Khrenov, P. A., \& Chestnova, T. V. (2013). Обзор методов борьбы с микробными биоплёнками при воспалительных заболеваниях [Review of methods of combating microbial biofilms in inflammatory diseases]. Вестник новых медицинских технологий. Электронное издание - Bulletin of new medical technologies. Electronic edition, (1), 48.

[12] Kremenchutskyi, H. M., Stepanskyi, D. O., Yurhel, L. H., \& Koshova, I. P. (2010). Інформаційні комунікації мікроорганізмів [Information communications of microorganisms]. Вісник Дніпропетровського університету. Біологія. Медицина - Bulletin of Dnipropetrovsk University. Biology. Medicine, 1(1), 66-70.

[13] Leng, T. A., \& Sesik, М. (2011). Как описывать статистику в медицине [How to describe statistics in medicine]. М. Практическая медицина - M. Practical medicine.

[14] Liao, J., Schurr, M. J., \& Sauer, K. (2013). The MerR-like regulator BrIR confers biofilm tolerance by activating multidrug efflux pumps in Pseudomonas aeruginosa biofilms. Journal of bacteriology, 195(15), 3352-3363. doi: 10.1128/JB.00318-13

[15] Linski, A. R., Mikucka, A., Szmytkowski, J., \& Gospodarek, E. (2009). In vivo biofilm on the surface of a surgical mesh implant. Polskie Towarzystwo Mikrobiologow Polish Society of Microbiologists, 58(4), 367-369. PMID: 20380148

[16] Lyamin, A. V., Botkin, E. A., \& Zhestkov, A. V. (2012). Problems in medicine related to bacterial films. Clinical Microbiology and Antimicrobial Chemotherapy, 14(4), 268-275.

[17] Moons, P., Michiels, C. W., \& Aertsen, A. (2009). Bacterial interactions in biofilms. Critical reviews in microbiology, 35(3), 157-168. doi: 10.1080/10408410902809431

[18] Morozova, N. S., \& Marievskii, V. F. (2009). Дезинфектологические аспекты проблемы борьбы с биопленкой [Disinfectological aspects of the problem of combating biofilm]. Профрілактична медицина (епідеміологія, мікробіологія, вірусологія, паразитологія, інфекційні хвороби) Preventive medicine (epidemiology, microbiology, virology, parasitology, infectious diseases), (2), 3-7.

[19] Ovnanian, К. O., \& Trchunian, А. А. (2009). Ультраструктурная архитектоника межклеточных контактов в биопленках бактерий in vitro $и$ in vivo [Ultrastructural architectonics of intercellular contacts in bacterial biofilms in vitro and in vivo]. Национальная академия Армении - National Academy of Armenia, 109(1), 78-85.

[20] Parshikov, V. V., Chebotar, I. V., Khodak, V. A., \& Samsonov, A. A. (2012). Исследование in vitro микробной биопленки на поверхности синтетических макропористых эндопротезов для пластики брюшной стенки [In vitro study of microbial biofilm on the surface of synthetic macroporous endoprostheses for abdominal wall repair]. Современные технологии в медицине - Modern technologies in medicine, (1), 15-20.
[21] Popat, R., Crusz, S. A., Messina, M., Williams, P., West, S. A., \& Diggle, S. P. (2012). Quorum-sensing and cheating in bacterial biofilms. Proceedings of the Royal Society B: Biological Sciences, 279(1748), 4765-4771. doi: 10.1098/ rspb.2012.1976

[22] Rebrova, O. lu. (2006). Статистический анализ медицинских данных. Применение пакета прикладных программ Statistica [Statistical analysis of medical data. Application of the Statistica software package]. М., Медисфера - М., Medisphere.

[23] Shirobokov, V. P., lankovskii, D. S., \& Dyment, G. S. (2010). Микробная экология человека с цветным атласом. Учебное пособие [Human microbial ecology with color atlas. Tutorial]. К.: ООО "Червона Рута-Турс - К.: ООО "Chervona Ruta-Turs.

[24] Struev, I. V., Semeniuk, V. M., Naumkina, E. V., \& Odinokii, A. I. (2008). Микрофрлора раневого канала при пирсинге языка, верхней и нижней губы и ее чувствительность к антибактериальным препаратам [Microflora of the wound channel with piercing of the tongue, upper and lower lip and its sensitivity to antibacterial drugs]. Институт стоматологии - Institute of Dentistry, 1(38), 94-95.

[25] Suleman, L. (2016). Extracellular bacterial proteases in chronic wounds: a potential therapeutic target?. Advances in wound care, 5(10), 455-463. doi: 10.1089/wound.2015.0673

[26] Tsyhanenko, A. la., Mishina, M. M., \& Kurbanov, R. A. (2010). Спосіб відтворення біоплівок мікроорганізмів in vitro [The method of reproduction of biofilms of microorganisms in vitro]. Патент № 47944 UA МПК G09B 23/00 - Patent № 47944 UA МПК G09B 23/00.

[27] Vinnik, lu. S., Serova, E. V., Andreev, R. I., Perianova, O. V., Rukosueva, T. V., Leiman, A. V., \& Michurov, E. I. (2013). Особенности формирования микробных биоплёнок на различных субстратах. Возможность изучения биоплёнок на желчных конкрементах [Features of the formation of microbial biofilms on various substrates. Possibility of studying biofilms on gallstones]. Современные проблемы науки и образования - Modern problems of science and education, (5), 323-323.

[28] Vorobey, E. S., Voronkova, O. S., \& Vinnikov, A. I. (2012). Бактеріальні біоплівки. Quorum sensing - "відчуття кворуму" у бактерій в біоплівках [Bacterial biofilms. Quorum sensing - "quorum feeling" in bacteria in biofilms]. Biosystems Diversity, 20(1), 13-22.

[29] Weigel, L. M., Donlan, R. M., Shin, D. H., Jensen, B., Clark, N. C., McDougal, L. K., ... \& Patel, J. B. (2007). High-level vancomycin-resistant Staphylococcus aureus isolates associated with a polymicrobial biofilm. Antimicrobial agents and chemotherapy, 51(1), 231-238. doi: 10.1128/AAC.0057606

[30] Zubov, N. N., Kuvakin, V. I., \& Umarov, S. Z. (2020). Cmamuстика в биомедицине, фрармации и фрармацевтике [Statistics in biomedicine, pharmacy and pharmaceuticals]. ООО ДиректМедиа-ООО DirectMedia. 